\title{
Penerapan Hukum Tidak Tertulis dalam Putusan Hakim
}

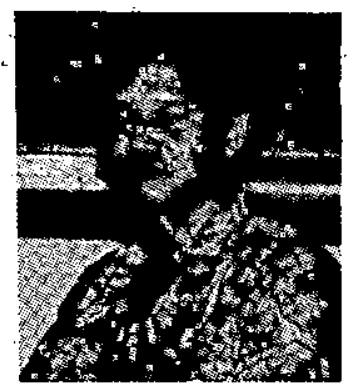

Oleh : H. Busyro Muqoddas

Bagi seorang hakim, untuk menerapkan hukum tak tertulis dalam putusannya, adalah hal yang dilematis, antara tuntutan untuk menerapkannya dalam kondisi tertentu, serta kesulitan teknis termasuk kapabilitas hakim.

H. Busyro Muqoddas, dalam tulisan berikut berusaha menggali, kapan dan dalam situasi bagaimana seorang hakim melakukan penerapan hukum tak tertulis dalam putusannya.

Adalah suatu hal yang sangat sering dan mungkin, dimana seorang hakim harus menerapkan hukum tidak tertulis dalam putusannya. Perkembangan kehidupan yang telah menggeser dan. merubah berbagai sektor-sektor urgen dalam. pola dan tata cara hidup, menuntut adanya penggunaan cara pandang (perspektif) yuridis yang lain di luar cara pandang dengan hukum tertulis. Di sinilah, upaya penelaahan secara serius terhadap bagaiamana penerapan hukum tak tertulis dalam putusan hakim mendapatkan urgensinya.

Tulisan ini bermaksud menyajikan problem yaing sangat sering dihadapi oleh para hakim khususnya, tentang penerapan hukum tidak tertulis (berdasarkan sebuah penelitian atau kasus), dan berikut juga diberikan alternatif solusi dan rekomendasinya.
Kedudukan Hakim Dalam Undang-undang No. 14 Tahun 1970.

Kajian mengenai hukum tidak tertulis dalam kaitannya dengan kedudukan dan tugas hakim, termasuk penelitian mengenai putusan hakim adalah merupakan kajian yang menarik, paling tidak berdasarkan dua alasan. Pertama, untuk mengetahui sejauhmana hakim memahami hukum tidak tertulis yang terdapat dalam masyarakat. Kedua, sejauhmana hakim menemukan nilainilai hukum tidak tertulis itu dan kemudian menerapkannya melalui putusanputusannya. Dengan kedua alasan itu pemikiran mengenai hukum tidak sekedar dapat dipahami dari-sisi idealnya yang bercorak abstrak, teoretis dan normatif, melainkan juga dari sisi cara penerapannya, dalam hal ini penerapan terhadap sengketa 
yang merupakan pertentangan kepentingan antar individu. Dalam kerangka demikian, tulisan ini dimaksudkan untuk memperoleh gambaran mengenai praktek penerapan asas iktikad baik, kesusilaan dan asas keputusan melalui putusan hakim.

Hukum dalam bentuknya yang tidak tertulis dapat ditemukan dalam masyarakat, yaitu berupa nilai-nilai hukum yang hidup dan dianut sebagai pandangan masyarakat mengenai sesuatu yang dianggapnya pantas dijadikan patokan atau pedoman dalam memutuskan suatu persoalan maupun sengketa.

Dalam sistem hukum positif kita, terdapat beberapa pasal yang menyebutkan mengenai nilai-nilai hukum ini, antara lain :

\section{Pasal 1 UU No. 14 Th 1970 dan}

penjelasannya sebagai berikut :

"Kekuasaan Kehakiman adalah Kekuasaan Negara yang merdeka untuk menyelenggarakan peradilan, menegakkan hukum dan keadilan berdasarkan peradilan menegakkan hukum dan keadilan berdasarkan Pancasila, demi terselenggaranya Negara Hukum Republik Indonesia."

"Kebebasan dalam melaksanakan wewenang judiciil tidaklah mutlak sifatnya, karena tugas dari pada Hakim dengan jalan menafsirkan hukum dan mencaridasar-dasar serta azas-azas yang jadi landasannya, melalaui perkara-perkara yang dihadapkan kepadanya, sehingga keputusannya mencerminkan perasaaan keadilan Bangsa dan Rakyat Indonesia."

\section{Pasal 27 (ayat 1) \\ UU No. 14 Tahun 1970 :}

"Hakim sebagaipenegak hukum dan keadilan wajib menggali mengikuti dan memahami nilai-nilai hukum yang hidup dalam masyarakat."

\section{Pasal 1337 KUHPerdata :}

"Suatu sebab adalah terlarang, apabila dilarang oleh undang-undang, atau apabila berlawanan dengan kesusilaan baik atau ketertiban umum".

\section{Pasal 1339 KUHPerdata :}

"Persetujuan-persetujuan tidak hanya mengikat untuk hal-hal yang dengan tegas dinyatakan di dalamnya, tetapi juga untuk segala sesuatu yang menurut sifat persetujuan, diharuskan oleh kepatutan, kebiasaan atau undang-undang".

Dari pasal-pasal di atas dapat diperoleh pengertian mengenai kedudukan dan tugas hakim, yaitu : Pertama, hakim menyandang kedudukan yang bebas dan merdeka dalam menjalankan kekuasaaan kehakiman; Keduà, hakim berkewajiban untuk memperhatikan dan menemukan dasardasar, asas-asas dari hukum tidak tertulis yang terdapat dalam kehidupan masyarakat; Ketiga, hakim berkewajiban untuk menafsirkan setiap undang-undang maupun perjanjian dalam memeriksa suatu sengketa, kearah suatu putusan yang mencerminkan perasaan keasilan masyarakat.

Kedudukan dan tugas demikian, ditinjau dari perspektif konflik atau sengketa adalah merupakan bentuk ketidak seimbangna hak dan kewajiban antara para pihak, dimana satu pihak merasa mengalami kerugian sementara pihak lain dinilainya mendapatkan keuntungan. Ditinjau dari sisi hukum, keadaan demikian harus diupayakan pemecahannya, yaitu pemecahan yang bertujuan untuk memulihkan kembali ketidakseimbangan hak dan kewajiban tersebut, sehingga para pihak berada pada kedudukannya yang seimbang. Upaya memulihkan ini dapat dilakukan hakim dengan memfungsikan hukum, mengingat fungsi pertama dari aturan hukum adalah 
sebagai alat untuk membagikan hak dan kewajiban diantara para anggota masyarakat (Algra, 1983 : 379-380).

Agar hukum dapat difahami fungsinya sebagaimana gambaran di atas, maka hukum harus dikuasai, terutama bagi kalangan hakim. Hal ini mengingat, bahwa hakim berkewajiiban untuk menggali, mengikuti dan memahami nilai-nilai hukum yang hidup dalam masyarakat, sebagaimana isi Pasal 27 (ayat 1) UU No. 14 Tahun 1970. Dalam pasal ini terkandung suaty arti bahwa penguasaan suatu hukum, tidak saja mencakup hukum dalam bentuk yang tertulis, namun juga hukum tidak tertulis maupun terhadap aspek-aspek dan kenyataan sosial yang dari padanya akan dapat dijadikan sumber hukum.

Tidak semua sengketa selalu dapat ditemukan aturannya di dalam undangundang. Hal ini di sebabkan pada kenyataan bahwa, tingkat kemajemukan kepentingan dan sengketa perkara bersifat lebih cepat dan kompleks dari pada perkembangan undangundang. Keadaan ini menyebabkan timbulnya masalah yaitu berupa kemungkinan kekosongan hukum, ketidak jelasan hukum dan ketidak lengkapan hukum. Sedangakan menurut Pasal 5 (ayat 1) dan Pasal 27 (ayat 1) No. 14 Tahun 1970, hakim harus memberikan putusannya berdasarkan hukum dan nilai-nilai hukum yang hidup dalam masyarakat. Dalam menghadapi masalah demikian, ia harus mencari atau menemukan hukumnya. Penegakan hukum dan pelaksanaan hukum sering merupakan penemuan hukum dan tidak sekedar penerapan hukum (Sudikno Mertokusumo, 1986 : 132). Dari istilah menemukan hukum, diperoleh kesimpulan bahwa hukum dalam pengertian ini, bukanlah dalam bentuk yang tertulis, melainkan berupa hukum tidak tertulis yang terdapat, tumbuh dan berkembang dalam masyarakat.
Beberapa Asas Hukum Dalam Hukum Tidak Tertulis

Hukum sebagai pernata (kelembagaan sosial) mengandung asas didalamnya. Mengingat kedudukan dan fungsi asas yang memiliki keterkaitan erat dengan hukum dan bahkan antara keduanya tak dapat dipisahkan, maka berikut akan dikemukakan pengertian asas.

"Asas adalah sesuatu kebenaran yang menjadi pokok dasar atau tumpuan berpikir (berpendapat dan sebagainya)" (Sri Soemantri Martosoewignjo, 1995 : 136).

"Asas adalah dasar kehidupan yang merupakan pengembangan nilai-nilai yang dimasyarakatkan menjadi landasan hubungan sesama anggota masyarakat" ( $M$ Solly. Lubis, $1995: 28$ ).

Jika pengertian asas di atas diintegrasikan ke dalam pengertian hukum. dapat diperoleh suatu pengertian mengenai asas hukum, ialah nilai-nilai kebenaran yang bersifat prinsipiil yang berfungsi sebagai pedoman dalam tata pergaulan masyarakat. Dalam pengertian yang lain dikemukakan oleh $P$ Scholten sebagaimana dikutip oleh Sudikno Mertokusumo bahwa, "Asas hukum adalah kecenderungan-kecenderungan yang disyaratkan oleh pandangan kesusilaan kita pada hukum, merupakan sifat-sifat umum dengan segala keterbatasannya sebagai pembawaan yang umum itu, tetapi yang tidak boleh tidak harus ada" (Sudikno Mertokusumo, 1986 : 32).

Dari pengertian asas hukum ini, melalui penelusuran terhadap beberapa pasal di atas, dapat dikemukakan adanya beberapa asas hukum, yaitu : asas kesusilaan, iktikad baik dan asaś kepatutan. Jika diringkas, berbagai asas hukum ini dapat diklasifikasi menjadi asas keseimbangan. Yang esensiil di dalam asas ini ialah terdapatnya keseimbangan antara hak dan kewajiban 
bagi para pihak yang bersengketa di pengadilan.

Persoalannya kemudian ialah, sejauh mana hakim menjadikan dan memfungsikan asas hukum ini dalam proses pembuatan putusannya. Dalam hal ini, ia berkewajiban memperhatikan pasal 23 (ayat 1) UU No. 14 Tahun 1970.

"Segala putusan pengadilan selain harus memuat alasan-alasan dan dasar-dasar putusan itu, juga harus memuat pula pasalpasal tertentu dari peraturan-peraturan yang bersangkutan atas sumber hukum tidak tertulis yang dijadikan dasar untuk mengadiil".

Berkenan dengan hukum tidak tertulis, keberadaan dan fungsi asas hukum menjadi sangat relevan, agar hakim dapat menggali nilai-nilai keadilan, kebenaran, kelayakan, kepatutan, kesusilaan dan iktikad baik yang terdapat di dalam hukum tidak tertulis. Nilainilai ini, untuk selanjutnya perlu diintegraskan dalam proses pembuatan putusan, dengan menggunakan penemuan hukum sebagai metode.

Pentingnya penemuan hukum bukan saja terletak pada diharuskannya hakim untuk mengadili dan memberikan putusan atas suatu perkara, namun juga, melalui penemuan hukum hakim dapat memberikan perlindungan hukum bagi pencari keadilan (justisiabelen). Sejalan dengan pendapat Sudikno Mertokusumo di atas, dimana penemuan hukum identik dengan penegakan hukum, maka perlu diperhatikan adanya tiga asas dalam menegakan hukum, yaitu asas kepastian hukum (rechtsischerheiit), asas kemanfaatan (zweckmassigkeit) dan asas keadilan (gerechtigkeit). Ketiga asas ini apabila diterapkan secara proposional dalam putusan hakim, akan dapat diperoleh suatu putusan hakim yang mendekati pada fungsi memberikan perlindungan hukum bagi para pencari keadilan.
Dalam perkara perdata, arti penting dari penemuan hukum terletak pada bagaimana hakim harus mampu untuk memulihkan keseimbangan antara hak dan kewajiban melaui putusannya. Sebab substansi dari hukum perdata adalah hak dan kewajiban yang menyangkut tata pergaulan perorangan dalam masyarakat. Hal ini mengandung arti bahwa, upaya memulihkan keseimbangan antara hak dan kewajiban harus memperhatikan aspek kemasyarakatan, seperti nilai-nilai kesusilaan, ketertiban umum, kepatutan dan kebiasaan, sebagaimana ditentukan dalam pasal 1337 dan pasal 1339 KUH Perdata. Dari kedua pasal ini dapat ditarik pengertian bahwa upaya menyeimbangkan hak dan kewajiban tidak dapat ditinjau atau diletakkan dalam kerangka kepentingan perorangan saja, namun juga dalam kerangka pertimbangan sosial kemasyarakatan.

\section{Putusan Hakim}

Dengan sifatnya yang normatif, suatu putusan hakim adalah merupakan hukum. Di dalamnya terkandung pertimbanganpertimbangan mengenai faktanya yang telah terbukti maupun alasan-alasan hukumnya yang sesuai dengan fakta itu, untuk kemudian diarahkan sesuai dan berdasarkan pada tujuan hukum. Tujuan dari suatu putusan hakim pada hakekatnya adalah merupakan tujuan hukum. Suatu putusan hakim akan dapat mencerminkan sifat/kepribadian hukumnya, jika putusan itu telah sesuai dengan tujuan hukum.

Tujuan hukum pada sasarannya adalah menciptakan tatanan kehidupan masyarakat secara tertib dan terdapatnya keseimbangan hak dan kewajiban di dalamnya. Dilihat dari sudut ini, maka hukum harus difungsikan kearah terwujudnya tujuan hukum di atas. Keseimbangan akan terwujud bila, antara hak dan kewajiban bersifat proporsional dalam kaitan kepentingan perorangan maupun 
kepentingan sosial. Dengan demikian hukum harus berfungsi mencegah jangan sampai terjadi pengurangan suatu hak dan pengurangan pemenuhan kewajiban yang akan berakibat terjadinya ketidakseimbangan dan ketidaktertiban dalam masyarakat. Dari sudut inilah, hukum harus seialu diarahkan pada tujuannya, yakni mewujudkan secara aktif suatu proses pembentukan masyarakat yang tertib, yang ditandai dengan terdapatnya keseimbangan antara hak dengan kewajiban.

Dengan melihat pentingnya arti tujuan hukum di atas, maka putusan hakim harus dapt berfungsi untuk mewujudkan tujuan hukum. Suatu putusan hakim dengan demikian harus memuat alasan-alasan yang bernilai yuridis. Mengingat pentingnya alasan yang demikian itu, maka amat tepatlah pembuat rumusan undang-undang yang mengatur perihal putusan hakim, seperti yang tersebut di dalam pasal 184 (ayat 1) HIR dan Pasal 23 (ayat 1) UU No. 14 Th 1970 :

"Keputusan hakim hendaklah berisikan ringkasan yang nyata dari tuntutan dan jawaban serta juga darialasan keputusan itu"

"Segala putusan pengadilan selain harus memuat alasan-alasan dan dasar-dasar putusan itu, juga harus memuat pula pasalpasal tertentu dari peraturan-peraturan yang bersangkutan atas sumber hukum tak tertulis yang dijadikan dasar untuk mengadii"

Dari pasal-pasal di atas dapat ditarik pengertian bahwa, putusan hakim harus mampu'mendistribusikan hak, dan pada saat yang bersamaan harus pula menentukan kewajibannya. Dengan pengertian ini, putusan hakim dapat memiliki siffat preventif (pencegahan) terhadap munculnya-suatu proses ketidaktertiban dalam masyarakat. Disinilah letak arti penting kajian mengenai penerapan hukum tidak tertulis melalui putusan-putusan hakim.

Bertitik tolak dari pentingnya kedudukan hukum tidak tertulis yang merupakan salah satu' unsur dari sistem hukum Indonesia, terlebih berkaitan dengan sejauh mana hukum tidak tertulis ini dijadikan unsur dalam proses pembuatan putusan hakim, selanjutnya dapat dikemukakan permasalahan sebagai berikut :

a. Bagaiamana praktek penerapan hukum tidak tertulis dalam putusan-putusan hakim.

b. Asas-asas Hukum Tidak Tertulis apakah yang terdapat di dalam putusan itu.

\section{Latar Belakang Penerapan Hukum Tak Tertulis : Sebuah Kasus}

Dari hasil penelitian yang berlokasi pada Pengadilan Negeri Sleman Daerah Istimewa Yogyakarta dalam kurun waktu delapan tahun yaitu dimulai tahun 1980-1988, diperoleh dua kasus yang menggambarkan terdapatnya penerapan hukum tidak tertulis pada putusan hakim. Ke dua putusan ini tersebut dalam perkara No. 55/1981.PdUG/ SImn dan No. 13/1982.Pdt/G/SImn; mengenai sengketa perjanjian jual beli dengan hak membeli kembali yang diatur dalam Pasal 1519-1532 KUHPerdata.

Di dalam praktik, perjanjian ini sering merupakan faktor pemicu sengketa antara pihak penjual dengan pihak pembeli, sehingga ke tingkat pengadilan. Secara prinsip, penyebab sengketa ini adalah terdapatnya unsur penyalahgunaan keadaán yang dilakukan oleh pihak yang secara sosial ekonomis memiliki kedudukan lebih kuat, terhadap pihak lain yang secara sosial ekonomi lemah kedudukannya. Hal ini dengan mudah dapat terjadi ketika seseorang berada dalam keadaan memerlukan matëri, untuk keperluan mana ia meminjam uaing kepada pihak lain. Oleh pihak lain ini, diberikan sejumlah uang, bukan dalám bentuk perjanjian hutang, namun dikonstruksi. sebagai perjanjian jual beli dengan tiak 
membeli kembali.

- Sebagaiamana pasal-pasal di atas, terdapat. ketentuan bahwa, penjual berkedudukan sebagai penjual sementara, yaitu dalam batas waktu yang disepakati dengan pembeli, untuk setelah ia menerima uang penjualan berhak melakukan pembelian kembali dalam tenggang waktu tersebut. Jika dalam tenggang waktu ini penjual barang tidak melakukan pembelian kembali atas barangnya, maka secara yuridis, ia kehilangan haknya atas barang itu, dan hak pemilikan barang berpindah kepada pihak pembeli.

Dalam kenyataannya, pihak penjual menerima uang penjualannya dalam jumlah yang tidak seimbang dengan nilai/harga barang yang dijuálnya. Dalam hal penjual tidak berhasil membeli kembali barangnya - pada umumnya disebabkan karena ketidak-mámpuannya untuk membeli kembali - maka pihak pembeli merupakan pihak yang secara pasti memperoleh keuntungan. Putusan hakim di bawah ini menggambarkan bagaiamana perjanjian jual beli dengan hak membeli kembali.

\section{Alasan putusan hakim membatalkan perjanjian}

a. Terdapatnya fakta bahwa, pihak pemilik (penjual) barang telah ménerima uang dari pembeli, yang nilainya tidak seimbang dengan harga barang. Dengan fakta ini, hakim menilai bahwa perjanjian jual beli dengan hajk membeli kembali antara penggugat dengan tergugat adalah merupakan perjanjian semu (pura-pura). Perjanjian yang isinya tidak mencerminkan prestasi seimbang antar para pihak, bertentangan nilai nilai-nilai hukum tidak tertulis, yang hidup dalam masyarakat.

b. Fakta ini dijadikan alasan oleh hakim yaitu, dengan tidak adanya prestasi timbal balik yang seimbang antara penggugat dengan tergugat, maka.hubungan hukum yang terjadi antara penggugat dengan tergugat, dikualifisir sebagai perjanjian hutang piutang dengan jaminan barang.

\section{Pembahasan mengenai alasan hakim}

Pembahasan ini mendasarkan pada beberapa asas-asas hukum, yaitu asas kesusilaan, iktikad baik dan kepatutan, guna mengetahui apakah asas-asas hukum yang terdapat dalam hukum tidak tertulis ini diterapkan oleh hakim dalam ke dua putusan di atas.

Ditinjau dari asas-asas hukum di atas, putusan hakim yang membatalkan perjanjian jual beli dengan hak membeli kembali menunjukkan terdapatnya pemahaman hakim yang cukup ketat terhadap-beberapa pasal di bawah ini :

\section{Pasal 1337 KUHPerdata yang isinya :} "Suatu' sebab adalah terlarang, apabila dilarang oleh undang-undang, atau apabila berlawanan dengan kesusilaan baik atau ketertiban umum"

\section{Pasal 1338 (ayat 3)}

KUHPerdata yang isinya :

"Persetujuan-persetujuan harus dilaksanakan dengan iktikad baik"

\section{Pasal 1339 (ayat 3) \\ KUHPerdata yang isinya :}

"Persetujuan-persetujuan tidak hanya mengikat untuk hal-hal yang dengan tegas dinyatakan di dalamnya, tetapi juga untuk segala sesuatu yang menurut sifat persetujuan, diharuskan oleh kepatutan, kebiasaan atau undang-undang".

Dalam putusan di atas, hakim telah melakukan penilaian terhadap keseluruhan fakta, apakah bertentangan dengan nilai hukum tidak tertulis seperti nilai-nilai kesusilaan, iktikad baik dan kepatutan. 
Demikian pula ia telah menilai apakah kesepakatan yang telah terjadi itu lahir secara bebas, tanpa ada unsur penyalahgunaan keadaan dari pihak yang kuat secara ekonomis terhadap pihak yang lemah.

Penilaian hakim didasarkan pada terdapatnya fakta bahwa, prestasi timbal balik antara pihak penjual dengan pihak pembeli tidaklah seimbang. Sejalan dengan asas restitutio inintegrum, yang bermuatan nilai keseimbangan, perjanjian antara para pihak dikualifikasi sebagai perjanjian hutang piutang. la telah menilai fakta. Fakta secara aktif diberi makna kemudian menafsirkan isi perjanjian, dan menemukan peraturan undang-undang yang dinilainya paling benar dengan obyektivitas fakta. Melalui penafsiran ini, ia telah menemukan hukumnya yang dianggapnya paling tepat, dan bukan sekedar menerapkan undang-undang secara sempit.

Asas iktikad baik sebagaimana diatur di dalam pasal 1338 (ayat 3) KUHPerdata, berfungsi untuk menambah, melengkapi, membatasi atau meniadakan isi suatu :perjanjian, agar dengan demikian, suatu perjanjian dapat merupakan perwujudan dari apa yang șebenarnya dikehendaki oleh para pihak. Fungsi demikian akan berjalan, bilamana hakim bersikap aktif dan cermat di dalam menerapkannya pada keseluruhan isi suatu perjanjian. Konsekuensinya, hakim seharusnya mampu untuk menilai, apakah isi suatu perjanjian bertentangan atau tidak dengan asas ini. Mengutip pendapat yang mengatakan bahwa : "asas iktikad baik yang banyak terdapat di dalam norma kepatutan dan keadilan bersangkut-paut dengan pentingnya persahabatan yang harus diperhatikan terhadap sesama manusia" (Algra, $1983: 74$ ), maka penilaian itu memiliki arti penting dalam hubungan antar manusia.

Tampak bahwa hakim melakukan penilaian secara cermat atas fakta yang menunjukkan adanya kehendak pemilik barang yaitu untuk mengajukan pinjaman uang dengan jaminan barang. Walaupun fakta ini tidak merupakan bukti autentik, namun karena mengandung nilai-nilai iktikad baik, hakim memberinya suatu alas pembenar melalui penerapan Pasal 1338 (ayat 3) KUHPerdata. Penerapan ini menunjukkan bahwa para pihak bukan hanya terikat oleh kata-kata perjanjian dan kata-kata perundang-undangan, melainkan juga terikat pada asas iktikad baik. Lebih dari itu, penerapan pasal ini - oleh hakim, menunjukkan pula penekanan arti penting asas ini, sebagai satu dari lima pasal terpenting dari seluruh Kitab Undang-Undang Hukum Perdata, sebagaimana diucapkan E.M.Meijers yang dikutip oleh P.L. Wery (P.L.Wery, $1990: 8$ ).

Disamping itu, causa halal (geoorloofde oorzaak), yang pengertiannya dapat diperoleh dengan cara penafsiran a contrario dari isi pasal 1337 KUH Perdata, oleh Hoge Raad di Belanda dirumuskan dengan : "apa yang dimaksudkan oleh para pihak dengan mengadakan perjanjian" (Volmmar, 1984' 158-160). Terdapat pendapat lain yangmengatakan bawa :."dengan pengertian oorzaak itu, diselidiki apakah tujuan dibuatnya perjanjian itu halal adanya, apakah isi perjanjian atau prestasi yang terhutang tidak bertentangan dengan undang-undang, ketertiban umum dan kesusilaan", (Sri Soedewi, 1975:30).

Pada putusan hakim di atas, terdapat penilaian kritis dari hakim terhadap isi per.janjian jual beli dengan hak membeli kembali, sekalipun perjanjian ini dituangkan dalam bentuk bukti otentik, namun karena isinya dinilai bertentangan dengan asas-asas hukum di atas, akhirnya dibatalkannya. Dapat ditarik pengertian bahwa, hakim menilai isi perjanjian yang diatur dalam pasal 1519-1532 KUHPerdata tidak lagi sesuai dengan konteks nilai-nilai kesusilaan, iktikad baik dan kepatutan yang terdapat di dalam hukum tidak tertulis yang hidup dalam masyarakat. 
Pendapat hakim demikian sejalan dengan watak undang-undang yang terbatas dari sudut ruang dan waktu, sebagaimana pendapat bahwa: "Suatu kaedah bukanlah hasil, sesuatu yang dianggap layak pada waktú dan tempat tertentu" (W.Van GGerven, téjémahàn Hartini Trenggono, 1973 : 17).

Konsekuensi dari pendapat Gerven ini, setiap peraturan perundang-undangan yang ișinya tidak sesuai lagi dengan nafas nilainilai hukum tidak tertulis yang di dalamnya terkandung asas-asas hukum di atas, perlu untuk disesuaikan dengan cảra, menjadikan asaśasas hukum ini sebagai unsur pokok untuk disenyawakan ke dalam pemahaman dan penáfsiran serta penerapan peraturan perundangan dalam suatu kasus konkrit. Dan hal init tampak pada kedua putusan hakim di atas.

\section{Kèsimpulan}

Dari keseluruhan uraian di atas, akhimya dapat diajukan kesimpulan sébagai beriktu : 1. Penerapan hukum tidak tertulis dalam sprakték putusan hakim hanya mungkin dilakukan hakim bilamana ia berpegang téguh pada jiwa ketentuan pasal 27 (ayat 1) UU No. 14 Th 1970 . Pelàksariaan pasal ini, memerlukan penguasaan "hakim terhadap materi kasus yang menjadi sengketa dan kemudian mencari serta menentukan pasal-pasal mana di antara hükụm tertulis yang paling mendekati kesesuaian dengan isi kasusnya, - kemudian mensenyawakan jiwa pasalpasal ini dengan asas-àsas hukum tidak teritulis yang hidup dalam masyarakat.

2. Proses mensenyawakan ini, dilakukan dengan menggunakan metode dialektika, yaitu dengan menentukan suatu unsur menjadi suatu tesa, diikuti dengan - menentukan unsur lain sebagai anti-tesa, lalu dilkuti dengan mensenyawakan antära dua unsur init yang hasilnya disebut dengan sintesa.
Metode semacam ini dapat merupakan alternatif pemecahan suatu kasus kearah suatu putsan yang mengandung muatan nilai-nilai keadilan, kepastian hukum dan kemanfaatan. Dengan demikian putusan hakim tidak besifat legistis-tekstual melainkan solutifkontekstual.

\section{Saran-Saran}

1. Mengingat semakin kompleks dan variatifnya berbagai kasus keperdataan sejalan dengan percepatan perubahan sosial, semakin diperlukan peningkatan wawasan pemikiran hakim dalam bidang hukum dan keterkaitannya dengan bidangbidang lainnya. Bidang lain ini terutama adalah ilmu-ilmu bantu seperti filsafat, sosiologi danmetode penemuan hukum.

2. Kajian maupun penelitian terhadap putusan hakim, perlu ditingkatkan, untuk mengetahui sejauh mana upaya pencari keadilan (justisiabelen) berhasil mendapatkan putusan hakim yang bermuatan keadilan, kepastian hukum dan kemanfaatan, sekaligus untuk menelusuri sejauhmana perkembangan dan kemajuan pemikiran hakim dalam penguasaan sumber-sumber hukum dan ilmu hukum yang bersifat dinamis.

\section{DAFTAR PUSTAKA}

Algra.NE, Van Duyvendijk K. "Mula Hukum", diterjemahkan oleh JCT. Simorangkir dkk, Binacipta, Bandung, 1983.

M.Solly Lubis. "Permusan Dan Pembinaan Cita Hukum Dan Penerapan Asas-Asas Hukum Nasional (Diitinjau Dari Aspek "Ketatanegaraan)", dalam Majalah Hukum Nasional Edisi Khusus, No. 2.1995, BPHN, Jakarta, 1995.

Srl Soedowl Masjchoen Sofwan. "Hukum 
Perutangan", Liberty, Yogyakarta, 1975.

Sri Sumantri Martosoewignyo. "Proses Perumusan cita Hukum Dan Asas-Asas Hukum Dalam Peeriode Tahun 1908 Sampai Sekarang", dalam Majalah Hukum Nasional, Edisi Khusus, No. 11995, BPHN, Jakarta. 1995.

Sudikno Mertokusumo. "Kebijaksanaan Hakim", terjemahan oleh Hartini Tranggono, Airlangga, Surabaya, 1990.
Van Gervenn, W. Kebijaksanaan Hakim", terjemahan oleh Hartini Tranggono, Airlangga, Surabaya, 1990.

Volimar, H.F.A. "Pengantar Studi Hukum Perdata", Jilid II, Rajawali Jakarta, 1984.

Wery, P.L. "Perkembangan Tentang Iktikad Baik di Nederland", Percetakan Negara, Jakarta, 1990.

*) H. Busyro Moqoddas, SH, MH, adalah alumni FH UII. Meraih gelar master pada Universitas Gadjah Mada. Kini, selain sebagai dosen di FH UII, juga sebagai Kepala PKBH (Pusat Konsultasi dan Bantuan Hukum) FH. UII. 